\title{
KURTULUŞ SAVAŞININ DİPLOMATİK BİR CEPHESİ-İNEBOLU (Mustafa Kemal-Harington Görüşmesi Meselesi)
}

\author{
Yrd. Doç. Dr. Rahmi DOĞANAY*
}

\section{ÖZET}

Kurtuluş Savaşı'nda askeri mücadele yanında diplomasi alanında da gerek İşgalciler, gerekse Türkler açısından girişimler mevcut olmuştur. Bunların asıl amacı problemi barış yoluyla çözmek niyetlerine dayandığı gibi, mücadele içinde avantaj sağlamaya yönelik diplomatik çıkışlar olarak da dikkat çekerler.

Mustafa Kemal ile bir görüşme isteğinde bulunan Müttefik ordulan Başkumandanı Harington'un iyi niyetli sayılabilecek girişimi de İngiliz diplomatların sabotesi ile karşılaşmış, iki tarafın "görüşme isteği kimden geldi?" noktasında çıkmaza sürüklediği ve atıl kalan bu girişı̇m 1921 yılı Haziran-Temmuz aylanında cereyan etmiștir. Sonuçsuz kalan bu adımın Türk-İngiliz anlaşmazlıklanının çözümünde bulunabileceği katkılar da böylece engellenmiştir. Bu görüşme girişimi çerçevesinde yaşanan tartı̧̧malar ve yazışmalar "Mustafa Kemal'in kaçırılması teşebbüsü"ne kadar uzanan spekülasyonlara yol açmıştır. Inebolu.

Anahtar Kelimeler: Kurtuluş Savaşı, Mustafa Kemal, Harington,

\section{SUMMARY}

There had been meetings dealing with both invaders and Turks in diplomatic area beside the military struggle in the Independence War. Although the main aims these meetings were to solve the problems peace fully, they were diplomatik steps to take advantages in the struggle.

Mr. Harington, the Chief Commander of Allied Forces, made an attempt which could be accepted as a good will gesture, but it was sabo-

* $\quad$ Furat Universitesi Fen-Edebiyat Fakültesi Oğretim Uyesi. 
taged by the British diplomats. There had been a crisis on the subject of who wanted the meeting and that attempt was cut off. This event took place between June-July of 1921 .

This attempt which could help to solve the disagreements between British and Turkish sides gave no result. The arguments and correspondence made in the view of that problem led a speculation "the attempt of kidnapping Mustafa Kemal".

Key Words: Independence War, Mustafa Kemal, Harington, Inebolu, Refet Paşa.

- Kurtuluş Savaşı sırasında İngilizlerin ağırlıklı olarak uyguladıkları güç kullanma politikası yanında, diplomasi yoluyla Sevr'e ulaşma veya Sevr'e yakın bir mutabakat sağlama gayretleri de görülür. Diplomasi yolunu tercih edenlerin azınlıkta olmalarına rağmen daha akılcı bir yol izledikleri de savaş sonrası gelişmelerden açıkca görülmektedir. Diplomatik çabaların samimiyeti tartışlabilir olmakla birlikte daha iyimser bir görüntü vermektedir.

- Mondros ve Sevr gibi antlaşmalardan sonra Anadolu'da şekillenen Milli Kuvvetin gücünü gören İngilizler, Türklerle ilişkilerini kendi çıkarları doğrultusunda iyileştirmeye çalışmışlardı. 1920 yılı sonlarında ve 1921 yilı boyunca Karadeniz limanlarına İngiliz gemileri ve temsilcilerinin gelmesi bu doğrultuda idi. Giresun, Trabzon, Inebolu, Rize gibi şehirlere gelen İngilizler ${ }^{1}$ resmi sıfat taşımamakla birlikte, Avrupa'nın ve özellikle İngiltere'nin Türklerle barış yapmak arzusunda olduklarını bildiriyorlard $1^{2}$. Mahalli mülki ve askeri yetkililerle görüşmeler yapıyorlar, görüşmelerde ticari ilişkiler kurulması isteği ortaya konuyordu. Bu gibi teşebbüsler yanında Ankara ile diplomatik ilişkiler kurulması yolunda en ciddi adım 1921 Haziranı'nda atılmıștı. Bunun miman İstanbul'daki İngiliz kuvvetleri Başkomutanı General Harington'du. Harington İstanbul'a geldiğinden beri İstanbul'da ve mümkünse Ankara'da Türklerle dostane ilişkiler kurmak için çalışmıştı. Müslüman mültecilere yardım ediyor, hayırsever balolan düzenliyordu. Ancak yüksek politika düzeyinde yakınlaşma olamıyordu³.

- 1921 Temmuz'unda başlayan Yunan saldırısından önce İngiliz General Harington diplomatik bir çaba başlatır. Bu adımın arkasında Yunan saldınsından başka Türk-Sovyet ilişkilerinin gelişmesi de önemli bir etkendir.

- 13 Haziran 1921'de İnebolu'ya gelen Hanry ve Shturton adındaki Ingiliz subaylan General Harington'un yakını olduklarını bildirip, İnebo-

Bilal N. Simsir, Ingiliz Belgelerinde Atatürk, Ankara, 1979, C. III, s. 113-114.

2. ATASE Arșivi, Kls. 615, D. 206, F. 62, 66.

3. Gotthard Jaescke, Kurtulus Savaşı ile llgili Ingiliz Belgeleri, Ankara, 1986, s. 225. 
lu'da bulunan Refet Paşa ile görüşürler. Subaylar sivil giyimlidir. Bir miktar cephane getirmişler ve bu işi sürdüreceklerini söylemektedirler. General Harington tarafından gönderildiklerini de belirtirler ${ }^{4}$. Görüşmede bundan başka, İnebolu'ya gelmek için cephane sevki vesilesinden yararlandıklanını, getirdikleri cephanenin Harington'un iyi niyetine işaret olarak kabul edilmesini ${ }^{5}$ rica ederler. General Harington'un Türkiyeci olduğunu, İngiltere kamu oyunun da Türklere meyilli olduğunu söylerler. Mustafa Kemal'in İnebolu'dan bir torpido ile İstanbul'a gelmesi ve Boğaziçi'nde Harington'un yalısında barı̧̧ esasları üzerinde gizlice görüşmelerini teklif ederler. Bu girişimin savaşın bitmesi için insani bir girişim olduğunu belirtirler. Subayların ifadesine göre, Yunanlıların İngiliz müdahalesiyle Anadolu'dan çıkarılması da esas olarak Müttefikler tarafından kabul edilmiş, yalnız İstanbul'da İngiliz, Fransız, İtalyan ve Türklerden kurulu bir kontrol komisyonu bulunması düşünülüyormuş. Türkiye'ye yardım edilmesi düşünülüyormuş. Londra'da alınan kararlar uygulanmadan önce Türklerle esaslı bir anlaşma yapmak istiyorlarmış. Türkler elindeki İngiliz esirlerin bir iyi niyet gösterisi olarak serbest bırakılmasını istiyorlarmış. Bu yapılırsa Malta'daki Türk esirlerin de serbest bırakılacağını açıklamışlaró . Görüşmeden sonra Binbaşı Hanry General Harington'a bir mektup yazıp, imzalı bir suretini de Refet Paşa'ya bırakmıştı. Mektupta görüşmeler hakkında bilgi vermişti ${ }^{7}$.

- İngiliz subaylarla yapılan görüşme Ankara'ya bildirilince Mustafa Kemal, Refet Paşa'ya nasıl davranacağı konusunda bir talimat gönderir $^{8}$. Mustafa Kemal bu subayların durumunun araştırılmasından sonra, Misak-1 Milli'ye uygun olmak üzere kabul edeceklerini bildirdikleri şart-

4. Y. Hikmet Bayur, Türkiye Devletinin Dış Siyasası, Ankara 1973, s. 95; aynca Kemal Atatürk, Nutuk, MEB yayın, Istanbul, 1982, C. II, s. 643; Ingiliz subayların Refet Paşa ile görüşmelerinin T.B.M.M. Reisi Mustafa Kemal'in talimatı ile olduğu anlaşılmaktadır. Sinop Cephesi Kumandanı Refet Pasa'ya T.B.M.M. Reisi özel kaleminden 13.6.1921 tarihinde çekilen telgraftaki ifadelere göre Mustafa Kemal'in gelen Ingilizlerden haberdar olduğu anlaşılmaktadır. Telgraf için bkz. Cumhurbaşkanlığ 1 Arsivi, A-III-7, D. 18, F. 84/13.

5. Nurettin Peker, Ingiliz subayların cephaneden başka ticari eşya da getirdiklerini, Shturton'un üsteğmen rütbesinde olduğunu yazar. Bkz. Nurettin Peker, Istiklal Savasının Vesika ve Resimleri, Istanbul, 1955, s. 348.

6. Cumhurbaşkanlığ Arşivi, A-III-7, D. 18, F. 84/11,

Görüşmede Refet Paşa'nın söyledikleri de Binbaşi Shturton'un 27.6.1921 tarihli raporunda yer almaktadır. Buna göre; Ankara Hükümeti Misak-1 Milli’ye ulaşmak için sonuna kadar savaşacaktı. Iyi teşkilatlı büyük bir ordu kurmuştu. Ayrıca Ankara Hükümeti'nin Sovyetlerle, Bulgaristan, Fransa ve Italya ile ilişkilerine, hilafet konusuna, Orta Doğu sorununa kısa kısa değinmişti. Ankara Hükümeti dış politikasında Ingiltere ile bir ittifak yapmayı düșünmüştü. Ama bu konuda oyuna gelmeyi, kendisiyle oynanmasın istemiyordu. Uzlaşma geçici değil sağlam ve sürekli olmalıydı. Esirlerin değiştirilmesi konusu da konuşulmuştu. Ayrıca Mustafa Kemal'in Ingilizlere sempati duyduğu da söylenmişti. Bkz. Bilal Şimşir, Sakarya'dan Izmir'e, Istanbul, 1989 , s. $57-58$.

7. Y. Hikmet Bayur, Türkiye Devletinin Dış Siyasası, s. 96.

8. Talimat için bkz. Cumhurbaşkanlığı Arşivi, A-III-7, D. 18, F. 84/8, 9. 
lar esas olarak İngilizlerle görüşmeye hazır olduğunu, General Ankara'ya gelmek isterse iyi kabul göreceğini ve bizzat görüşeceklerini, ön görüşmeyi Refet Paşa'nın kendisinin de yapabileceğini, İnebolu'daki Ingiliz subayların bu tebligat üzerine İstanbul'la telgrafla görüşerek neticeyi Refet Paşa'ya bildirmelerini ve Refet Paşa'nın da kendisini bilgilendirmesini ister. $\mathrm{Bu}$ açıklamalar doğrultusunda İngiliz subaylar İstanbul'a döner.

- Bu yazışmalardan sonra 18 Haziran'a kadar bu konuda bir gelişme görülmez. Ancak 18 Haziran'da Kızılay İkinci Başkanı ve Ankara'nın fahri temsilcisi durumundaki Hamit Bey'den bir telgraf gelir. Bunda, İngiliz Yüksek Komiserliği adına resmi sıfat taşıyan bir zatın kendisine müracaatla çabuk barıs yapabilmek için derhal ilişkiye girmek istedikleri ve acele cevap bekledikleri bildirilmişti ${ }^{9}$. Ancak Hamit Bey'in telgrafının neye dayandığı hususunda bir bilgi yoktu.

- İngiliz belgelerinde bu görüşme girişimi ile ilgili bilgiler, $20 \mathrm{Hazi}-$ ran tarihinden itibaren ortaya çıkmaktadır. İstanbul'daki Müttefik Ordulan Kumandanı Harington'un İngiltere Savunma Bakanlığına çektiği telgrafla; İnebolu'ya gelen İngiliz subaylarından, onların iyi karşıılandığından, Mustafa Kemal'in Ankara'ya gelmelerini istemesinden ve sağnak yağmur yüzünden bunun gerçekleşemediğinden bahseder ve Refet Paşa'nın görüşmeler için tayin edildiğini bildirir. Harington, Mustafa Kemal'in Fransız ve Yunanlılara kızgın olduğunu, Rusya'dan yardımdan başka bir şey beklemediğini ve İngiltere ile iliş̧kilerini iyileştirmek istediğini de belirtir ${ }^{10}$. Telgrafla Harington, Mustafa Kemal'in kendisi ile görüşmeye pek istekli olduğunu, Binbaşı Hanry'nin İnebolu'dan Ankara'ya gitmesi için araba temin ettiğini, Hanry'nin emekli bir subay olduğunu ve maden işi için Anadolu'ya gittiğini belirtir. Harington, Hanry'nin Anadolu'daki Ingiliz esirlerin durumlarının belirlenmesi ve olursa serbest bırakılmalarını sağlamak için talimat verdiğini de belirtir. Mustafa Kemal ile görüşme isteğinden bahsetmez.

- Hanry ise, İnebolu'ya geldiğinde emekli olduğunu söylememiştir. Aynca Türklere verilmek üzere bazı askeri ve ticari malzeme getirmiş. Harington'un Mustafa Kemal ile görüşme isteğinden bahsetmiştir. Mustafa Kemal'in Hanry'e Ankara'ya gelmesi için araba tahsis etmesi, Hanry'nin tüccar olmaktan başka bazı özellikler taşıdığını göstermektedir. Gerçi araba tahsisi işinden Türk kaynaklanında ve yazışmalarda bahsedilmemiş olması böyle bir şey olup olmadığı konusunda da bir tartışma açmaktadır.

- General Harington'un 20 Haziran tarihli telgrafindan sonra konu İngiliz yetkili organlarının tartışması ve Harington'a verilen talimatlarla

9. Kemal Atatürk, Nutuk, Istanbul, 1982, C. II, s. 643.

10. Bilal Şimşir, Sakarya'dan Izmir'e, Istanbul, 1989, s. 50, aynca bkz. Bilal Şimşir, Ingiliz Belgelerinde Atatürk, C. III, s. 426. 
gündemde tutulmuştu. 21 Haziran'da İstanbul'daki İngiliz Yüksek Komiseri Vekili Rattigan'ın, Dışişleri Bakanı Lord Curzon'a çektiği telgrafta, Mustafa Kemal ile görüşmeye izin verildiği taktirde Mustafa Kemal'in kıyıda bekleyecek İngiliz savaş gemisine çağrılması, yalnız söyleyeceklerinin dinlenmesi, görüşmenin İngiliz gemisinde yapılması, İngiltere'nin Kemalistler peşinde koşmadığının açıklanması gerektiği, kendisinin bu görüşmeye karşı olduğu belirtiliyordu. Aynı gün Ingiliz Dışişleri görevlilerinden D.G. Osborne bir muhtıra hazırlayarak olayın İtalya ve Fransa'ya bildirilmesini, görüşme yapılırsa onlardan da temsilciler bulunmasını istiyordu ${ }^{11}$.

- Osborne'a göre; Mustafa Kemal görüşme konusunda İngiltere'yi müttefiklerinden ayırmak gibi bir taktik içindeydi. Mustafa Kemal İnebolu'ya gelemeyecek kadar aşırlar etkisinde ise Ankara'yı temsil et- mesi de mümkün değildi. Bu görüş Mustafa Kemal'in İnebolu'ya İngiliz gemisine gelmeyi kabul etmemesi üzerine ortaya atılıyordu. Mustafa Kemal Kemal'in aşırıların etkisinde olduğu fikri de, Refet Paşa'nın Mustafa Kemal'in İstanbul'a gidemeyeceğini, çünkü aşırnlar ve muhaliflerin bundan faydalanmak isteyeceğini söylemesinden kaynaklanıyordu.

- Yine 21 Haziran günü İngiliz Bakanlar Kurulu toplanmış, konuyu tartışmıştı. Yaygın görüş, Ankara'nın Bolşevik nüfuzuna girmesini engellemek için görüşme isteğinin kabul edilmesi, ancak Müttefiklerin arabuluculuk teklifine Yunanistan'ın vereceği cevabın beklenmesi ve İtalya ile Fransa'nın da görüşlerinin alınmasından sonra cevap verilmesiydi ${ }^{12}$.

- Harington'un deyimiyle "olağanüstü bir gelişme" olan bu görüşme girişimleri Ankara-Londra ilişkileri açısından olduğu kadar diğer bazı yönlerden de önemliydi. Ankara Hükümeti gücünü kabul ettirmişti. İç ayaklanmalan bastırıp içerde otoriteyi sağlamış, düzenli ordulanyla doğuda Ermenileri, güneyde Fransızları yenip ateşkes imzalamıştı. Batıda I. ve II. İnönü zaferlerini kazanmış, Moskova ile diplomatik ilişkilerini geliştirmiş, 1921 Martı'nda anlaşma imzalamıştı. Fransa ve İtalya ile ilişkileri de gelişmekteydi. İngiltere ile ilişki kurulamamış, bu başarılardan sonra Yunanistan'a arabuluculuk teklif ederek barışı sağlamak ve Türk-Sovyet yakınlaşmasını önlerken Ankara'nın İngiliz politikası karşısında daha önemli başarılar kazanmasını önlemek istemişti. $\mathrm{Bu}$ arada genel eğilim Ankara'yı muhatap almamaktı. Yunanistan'a yaptıkları arabuluculuk önerisini gizli tutuyorlardı. Yunanlılar ise Anadolu'da yapacakları taarruz için hazırlanıyordu. Bu sıralarda İngiliz yetkililer arasında Türklerle anlaşmaya, hatta görüşmeye taraf olan Harington'dan başka çok kimse yoktu. İngiliz diplomatlar görüşmeye kökten karşıydılar. Bu, onlara göre Mustafa Kemal karşısında itibar kaybı ve geri adım olacaktı.

11. Bilal Şimşir, Ingiliz Belgelerinde Atatürk, C. III, s. 428-429.

12. Bilal Şimşir, Ingiliz Belgelerinde Atatürk, C. III, s. 430. 
- 22 Haziran günü, İngiliz Hükümetince konu tartışılmaya devam edilir. Harington'a gönderilecek talimat belirlenir. Talimatta; görüşmenin yararlı olabileceği ancak henüz erken olduğu, Türklerin Sovyetlerle ilişkileri konusunda uyarılması, Harington'un yanında tecrübeli bir diplomatın da bulunması önerilir. Aynı gün Fransa ve İtalya'ya buralardaki büyükelçilikleri aracılığıyla Mustafa Kemal'in görüşme isteği bildirilir ${ }^{13}$. İtalya ve Fransa'dan olumlu cevap alınır.

- Fransa ve İtalya'nın cevabı gelmeden İstanbul'daki İngiliz Yüksek Komiser vekili Rattigan, Lord Curzona Ankara ile gizli müzakerelere girişilmesine karşı olduğunu belirtir. Rattigan ayrıca 18 Haziran'da Hamit Bey tarafından çekilen telgrafa Ankara'nın verdiği cevaptan da bahseder. Bu telgraf, "İngilizlerle görüşmeye hazınz. Ona göre karar verilmek üzere görüşmelerin gizli veya açık mı? Nerede ve kiminle veya hangi makamla görüşüleceğinin bildirilmesini dileriz." şeklindedir ${ }^{14}$. Rattigan cevabi telgraftan bahsedip, eğer illa da görüşülecekse, Harington'un Mustafa Kemal'le bir İngiliz savaş gemisinde görüşmesini, sadece söyleyeceklerini (söyleyecek önemli bir şeyi varsa) dinlemesini istiyor$\mathrm{du}^{15}$.

- İngiliz diplomatlar Milli Mücadele'yi görmezden geliyorlar, Mustafa Kemal'i muhatap almayı gurur meselesi yapıyorlardı. Yazışmalann ve olursa görüşmelerin gizliliği de bundan kaynaklanıyor olmalıydı. Mustafa Kemal'i bir İngiliz savaş gemisine davet ederken görüşmelerin yapılmamasını istiyor gibiydiler. Bunun yanında General Harington görüşme fikrini hararetle benimsemişti. Mustafa Kemal ile görüşmek için İngiliz Hükümeti'nden israrla izin istemiști. Görüșmeyi gerekli görüyordu. Mevcut kuvvetler Türklere Sevr'i zorla kabul ettiremezdi. Harington'a kalsa İnebolu'ya gidip görüşmeyi yapacaktı. Fakat İngiliz diplomatlar ve özellikle de Rattigan ile Baştercüman Rayn bunu engelliyorlardı. 3 Temmuz'da Shturton'un raporu ile birlikte Rayn'ın notu Rattigan tarafindan Curzon'a sunuldu. Rayn notunda; "Kemalistlerin İngiltere'yi oyuna getirmek istediklerini, Ankara Hükümeti'ni tanıtmaya çalıştıklarını, aslında Misak-1 Milli'den başka bir şey düşünmediklerini" ileri sürüyor, görüşme şartlannı şöyle belirliyordu: a- İngiltere banı̧ için muzafferin peşinde koşmuyordu. b- Türkiye'nin meşru hükümeti olan Padişah Hükümeti'nin arkasından iş çevirmiyordu. c- Ingiltere gürültüye pabuç bırakmıyordu. Türkiye'ye toprakları üzerinde makul bir bağışa istekli olmakla birlikte, doğudaki İngiliz çıkarlarının tehdit edilmesini ve azınlıkların yok edilmesini kabul edemezdi. d- Türk entrikalarının Fransa'yla İngiltere arasına bir kama sokmasına izin verilmeyecekti ${ }^{16}$.

13. Bilal Simșir, Sakarya'dan Izmir'e, s. 433.

14. Y.H. Bayur, XX. Yüzyılda Türklügün Tarih ve Acun Siyasası Uzerindeki Etkileri, Ankara, 1974, s. 213.

15. Bilal Simsir, Sakarya'dan Izmir'e, s. 63.

16. Bilal Șimșir, Ingiliz Belgelerinde Atatürk, C. III, s. 453-457. 
- Rayn'ın ifadelerine göre Türklerin bağımsız ve insanca yaşama isteği, İngiltere'nin cömertlik derecesine bağlanıyor, bu haklar İngilizlerce bağıs olarak niteleniyordu. Azınlık hakları savunulurken Türk milletinin hakları yok sayılyor, bazı ağışlar söz konusu ediliyordu.

- 13 Haziran'da basslayan ilişkiler 18 Haziran'da Hamit Bey'in telgrafından sonra durmuş, 7 Temmuz'a kadar İngilizler kendi aralarında takınacakları tavır konusunu tartışmışlar ve yazmışlardı. İngiliz diplomatlar görüşmeye karşı çıkmışlar, askerler ise yanında olmuşlardı. Görüşmeyi yapacak olan Harington, 3 Temmuz 1921 tarihinde İngiltere Savunma Bakanlığına gönderdiği şifreli telgrafta; İzzet Paşa aracılığıyla Mustafa Kemal Paşa'ya, görüşmek üzere Ajax gemisiyle İnebolu açıklarında bulunacağını, söyleyeceklerini dinleyip hükümetine bildireceğini, Mustafa Kemal'den sorması gereken bir konu varsa bildirilmesini, görüşmelerde hiç kimseyi taahhüt altına sokmayacağını, Yüksek Komiserlik ve Bahriyeden birer temsilcinin gemide bulunmasını önereceğini, buluşmanın Yunan taarruzu başlamadan yapılması gerektiğini bildirir ${ }^{17}$. Harington Yunan taarruzu başlamadan görüssmek istemektedir. O halde Yunan saldırısını bilmektedir. Yunan saldınıs bilindiğine göre, görüşmeler hakkında "Türkleri oyalama taktiği" nitelendirmesi yapanlanın haklı olduklan kanaati güçlenmektedir. Yüksek Komiser Vekili Rattigan'in 4 Temmuz tarihli ve Lord Curzon'a çektiği telde de; Yunan saldırısı başlamışsa Mustafa Kemal'in kıyıya gelmesinin zor olduğu belirtiliyordu. Ancak 2 Temmuz'da Harington'a, Rattigan görüsmelere katılmasa bile Mustafa Kemal'le görüşmesi, O'nu dinlemesi talimatı Londra'dan verilmişti' ${ }^{18} .5$ Temmuz'da Mustafa Kemal'in İngiliz esirler konusunda uyarılması da Harington'dan istenmişti.

- Nihayet İngiliz makamları arasında sürüp giden yazışmalar sonrasinda, General Harington'un Mustafa Kemal'e mesajı, Hamit Bey'in raporu ile birlikte özel bir kuryeye verildi. Speedy adlı Ingiliz gemisi kuryeyi alarak 4 Temmuz gecesi İstanbul'dan ayrildı. Aynı tarihli bir raporla Rattigan Curzon'a olayı rapor ediyor, mesajın Mustafa Kemal'e ulaştırılmak üzere Osmanlı Hariciye Nazırı'na verildiğini belirtiyordu ${ }^{19}$. Rattigan Hariciye Nazırı'nı devreye sokarak İstanbul'un devre dışı bırakılmadığını göstermek istiyor, Padişah'a da bu konuda garanti verileceğini ekliyordu.

- Harington mesajında; "Görüşmek istediğinizi Binbaşı Hanry aracılığıyla öğrendim. Inebolu veya İzmir'e gidip görüşme yapabileceğim. Sizi dinleyip İngiliz Hükümeti'ne rapor etmeğe yetkiliyim, ama İngiltere adına müzakereye yetkim yok. Görüşme İngiliz gemisinde

17. Bilal Simsir, Ingiliz Belgelerinde Atatürk, C. III, s. 452

18. Bilal Simșir, Sakarya'dan lzmir'e, s. 80.

19. Bilal Șimșir, Ingiliz Belgelerinde Atatürk, C. III, s. 462. 
yapılacaktır. Kabul ediyorsanız lütfen size uygun gün ve saati telleyiniz." ${ }^{20}$ diyordu.

- 6 Temmuz'da Ankara'ya ulaşan bu mesajla görüşme isteği hangi taraftan geldi tartışması da başlıyordu. Aynı gün Mustafa Kemal Harington'a şu cevabı verdi: “Ekselans General Harington'a; Mektubunuzu aldım. Yapacağımız görüşmede bir yanlış anlamayı gidermek için aşağıdaki hususu şimdiden belirtmek zorundayım. 13 Haziran günü Binbaşı Hanry ve arkadaşları İnebolu'ya gelerek Refet Paşa'ya, Ekselanslannın benimle görüşmek istediğini bildirdiler. Bu teklifler Binbaşı Hanry'nin size yolladığı ve imzalı ömeğini bize verdiği mektubunda da belirtildi. Aramızda başlayan doğrudan yazışmanın çıkıs noktası böyledir. Tam bağımsızlığımız kabul edildiği taktirde görüşmelere hazınz. Müzakerelerin Inebolu'da karada yapılması gerektiği kanaatindeyiz. Orada en iyi kabul göreceksiniz. Sadece görüs alışverişi yapılacaksa meslektaşlanımızdan birini görevlendirebiliriz"21. Bu mektuptan sonraki gelişmeyi de Mustafa Kemal Nutuk'ta şöyle anlatır; "İngiliz General ve yetkililer bu mektuba cevap vermek yerine, Yüksek Komiser Vekili Rattigan Hamit Bey ile Hariciye Nazın İzzet Paşa'nın makamında görüşmüş, Hanry'nin tüccar olarak İnebolu'ya gittiğini, yetkili olmadığını, sadece Anadolu'daki esirler hakkında aldığ ${ }_{1}$ bilgileri bildirmesinin istendiğini belirtiyordu. Milli Kuvvetlerin İstanbul'a geçip geçmeyeceğinin öğrenilmesi de Hanry'ye verilen görevlerdendi. Hamit Bey bu görüşmede söylenenleri Ankara'ya telledi. İlişkiler burada kesildi”22.

- 7 Temmuz'da Harington ve Rattigna İngiliz Savunma ve Dişişleri Bakanlıklarına gönderdikleri telgraflarda, Mustafa Kemal'den cevap geldiği, şartlarını bildirdiği ve Hanry'nin yetkilerini aştığının anlaşıldığı bildiriliyordu. Rattigan daha da ileri giderek Mustafa Kemal'in tatminkar olmayan cevabı karşısında Osmanlı Hariciye Nazırı ile görüșeceğini, kimsenin Mustafa Kemal'le görüşme istemediğini söyleyeceğini, Mustafa

20. Bilal Simşir, Ingiliz Belgelerinde Atatürk, C. III, s. 463.

21. Bilal Şimşir, Ingiliz Belgelerinde Atatürk, C. III, s. 470, Kemal Atatürk, Nutuk, MEB, 1982, C. II, s. 643-744, aym konuda Y. Hikmet Bayur, Türkiye Devletinin Dis Siyasası, s. 97 .

22. Kemal Atatürk, Nutuk, Istanbul, 1982, C. II, s. 645.

Y. Hikmet Bayur'a göre Hamit Bey Rattigan'in tzzet Paşa ile olan görüşmesindeki konuşmasını yumusatarak aktarmıștır. Rattigan Makamda; "Ilke olarak görüşmeye başlamadan önce Türklerin ulusal sınırları içinde tam bağımsızlığını tanımamız yolundaki istek dolayısıyla bu konuda daha ileri gidemeyiz. Kemalistler böyle bir istekte bulunmakla akıllanın kaybetmişe benziyorlar. Bizi ilgilendirdiği ölçüde olayı kapanmış sayıyoruz. Işe önce kimin giriştiği yolundaki anlaşmazlık aynı tutulursa önerilen temel sorun dısıdır. Eğer Kemal tutumunu baștan aşağı değistirirse Majeste Hükümeti konuyu yeniden ele alabilir. Oyle sanıorum ki, Enver'le lttihat ve Terakki Komitesinin Ankara'da derece derece duruma egemen olmakta bulunduklarından ve Kemalist Hükümetin tamamıyla Bolseviklerin elinde olduğundan kusku edilemez". Bkz. Y. Hikmet Bayur, XX. Yüzyılda Türklüğün Tarih ve Acun Siyasası Üzerindeki Etkileri, s. 217. 
Kemal'in isteklerinin kabul edilebilecek gibi olmadığını, Mustafa Kemal'in peşinden koşuyormuşuz gibi bir izlenimin hemen silinmesi gerektiğini belirtiyordu ${ }^{23} .8$ Temmuz'da Lord Curzon Rattigan'a cevabında, meselenin bir hükümet işi olduğunu, İstanbul'da İngiltere'yi bağlayacak bir davranıştan sakınması gerektiği ve talimat almadan Mustafa Kemal'e cevap verilmemesini bildirir. Rattigan aynı gün Mustafa Kemal ve Milli Mücadele ile ilgili görüşlerini Curzon'a tekrarlar ve İngiltere'nin görüssmeye niyetli olmadığının bildirildiğini yazar. Aynı tarihte Harington'un Savunma Bakanlığına cektiği telde de; Rattigan'ın izlenimlerinin yanlış olduğu, Mustafa Kemal'in hâlâ görüşme isteğinde olduğu belirtilmiștir ${ }^{24}$.

- 9-10 Temmuz günleri de İngiltere ile İstanbul arasında sıkı bir muhabere olur. General Harington ilişkilerin kesilip atılmaması ve görüşme için zemin hazırlamaya çalışırken, Yüksek Komiser Vekili Rattigan görüşme ihtimalini ortadan kaldırmak için uğraşır. İstanbul'da Londra'dan gelecek talimatlan beklemeden veya onların aksine girisimlerde bulunarak oldu bittilerle görüşmeyi engellemek ister ve bunu başarır da. Rattigan, Mustafa Kemal'in cevabı karşısında İngiltere'nin Yunanistan'dan yana bir politika izlemesini, İstanbul'un üs olarak Yunanistan'a kullandırılmasını, Ankara'da hakim olan aşırılarla anlaşmanın mümkün olmadığı$\mathrm{n}$ da telkin ediyordu ${ }^{25}$. Bu görüşlerini İtalyan ve Fransız Komiserlerin de paylaştıklarını da ileri sürüyordu.

- Londra'da Dışişleri Bakanı Lord Curzon da konuya Rattigan'dan daha olumlu yaklassmıyordu. O da İtalya ve Fransa'ya elçilikleri aracılığıyla konu ile ilgili bilgi verirken Rattigan'ın görüşlerini ele alıyor, Mustafa Kemal'in zaman kazanmak ve Müttefikleri ayırmak düşüncesinde olabileceğini de ekliyordu.

- Harington görüşme için hala olumludur. 9 Temmuz'da Savunma Bakanlığına çektiği telde, Mustafa Kemal'le iki asker olarak görüşmenin bile yararlı olabileceğini savunur. 10 Temmuz'da Harington bir kere daha Mustafa Kemal'le görüşme kapılarının tamamen kapanmadığını bildirip talimat ister. Ancak Yunan saldırısı başlayınca bu konu da sürüncemede kalır.

- Mustafa Kemal'le görüşülmeyeceği daha 10 Temmuz veya öncesinde Yunanistan'a duyurulmuş, Yunanlılara saldın için adeta işaret verilmişti. Yunanlılarnn Sakarya'ya kadar süren ilerlemeleri İngiltere'nin Türkiye ve Müttefikleri ile olan iliskilerinde kendi politikasını kabul ettirme

23. Bilal Şimşir, Ingiliz Belgelerinde Atatürk, C. II, s. 472.

24. Bilal Simsir, Ingiliz Belgelerinde Atatürk, s. 476.

25. Istanbul'da Ingiliz Yüksek Komiser Vekili Rattigan'dan Ingiltere Dıșişleri Bakanı Lord Curzon'a çekilen şifre telgraf. Bkz. Bilal Şimşir, Ingiliz Belgelerinde Atatürk, s. 478 . 
yönünden yürütecekti. Türkiye açısından ise, İngiltere ile görüşüp anlaşmanın mümkün olmadığ 1 anlaşılmıșt ${ }^{26}$. General Harington ve Savunma Bakanlığı görüssmeye taraftarken, diplomatlar Rattigan'ın oldu bittilerinin de etkisi ile görüşme umutlarını yok etmişlerdi. Bununla birlikte İngilizlerin Temmuz sonuna kadar konu ile ilgili yazışmaları da sürdürmüşlerdi. 14 Temmuz'da Fransa Dışişleri Bakanı M. Briand, Harington-Mustafa Kemal görüşmesi ile ilgili görüşünü yazılı olarak bildirdi: "Doğuda barış yapılabilmesi için hiçbir fırsatı kaçırmamak ve böyle bir firsatı ihmal etmenin de siyasi bir hata olacağı düşüncesiyle Mustafa Kemal-Harington görüşmesi fikrine katılmış olduğunu" belirtmiştit ${ }^{27}$. Diğer taraftan Harington hala görüşmenin yapılabileceği düşüncesindeydi ve 15 Temmuz tarihli telgrafında Savunma Bakanlığına, Milliyetçilerin kızdırılacağını, görüşme kapısının böyle sert bir şekilde kapatılmasının zararlı olacağını belirtiyordu. 18 Temmuz'da, Yunanlılar yenilirse Milliyetçilerin kısa sürede İstanbul'a geleceklerini, Mustafa Kemal'e verilecek cevap konusunda talimat beklediğini bildiriyordu. 20 Temmuz'da Curzon ve Kidston, Rattigan'a Fransa ve İtalya Hükümetlerine danıştıktan sonra, Mustafa Kemal'e cevap vermenin gerekli olmadığı görüşünü belirtiyor ve eğer görüşmek istiyorsa bundan sonraki adımı atmak Mustafa Kemal'e düşer diyorlardı. 26 Temmuz'da Harington'a görüşmenin reddedildiği cevabı açık olarak bildirildi ${ }^{28}$.

- Bu yazışmalar yapıldığı ve konunun görüşme isteği hangi taraftan çıktı noktasına yıkıldığı sıralarda, 10 Temmuz'da Yunan saldırısı başladı. $\mathrm{Bu}$ durumda Ingiliz Yüksek Komiserliği görüşme fikrini tamamen bırakıp, Yunan yanlısı bir politika izlenmesini savunmaya başladı. Mustafa Kemal'in istediklerini kabul etmek, O'na teslim olmaktı. Bu bakımdan Türk-Yunan savaşında tarafsızlığını Yunanlılar lehine bozdu. Çanakkale ve İstanbul Boğazlarını Yunan gemilerine açtı. Bu gemiler Marmara ve İstanbul'da üslenip, ikmal yaptıktan sonra Türk limanlanın vurdu. İngiltere bunlara göz yumdu. Böylece İngiltere'nin çok ağır olarak nitelediği şartlardan Milliyetçileri vaz geçirmek, adeta burunlarını sürtmek gibi bir tavır içine girdiği görülüyor. İngiltere bunu sağlayabilirse Sevr şartlarını Türklere kabul ettirebileceğini düşünüyor olmalıydı. Yunanlıların Sakarya'ya kadar ilerlemeleri İngilizleri bu konuda epeyce iyimser bir havaya da sokmuştu.

- Mustafa Kemal-Harington görüşmesinin gerçekleşmemesinde her iki tarafın beklentileri arasında önemli uçurumlar bulunmasının, hatta ortak yönlerinin bulunmamasının önemli bir etkisi olmuştu. Ancak bunun kadar önemli ve daha başlangıçta görüşüllüp görüşülmemesi konusu ve görüşme şartlarını gölgede bırakan bir başka tartışma, görüşme teklifinin

26. Bilal Simşir, Sakarya'dan tzmir'e, s. 95.

27. Bilal Şimşir, Sakarya'dan Izmir'e, s. 95.

28. Bilal Şimşir, Sakarya'dan Izmir'e, s. 97-99. 
ilk olarak kimden geldiği konusu üzerinde yapılmıştı. Anlaşıldığı kadanyla her iki taraf görüssme teklifinde bulunmayı bir zayıflık işareti sayıyor, itibar kaybetme endişesi yaşıyordu. İngiltere için Müttefiklerini kaybetme endişesi de gündemdeydi. Konu ile ilgili yazışmalara bakıldığında ifadelerden bu konuda bir kanaate varmak mümkün görünmesine rağmen, olayın gizli tutulması ve resmi makam ve mevkilerden ziyade şahıslar ve onların tavırlarının ön planda bulunması dolayısıyla kesin bir görüş belirtmek zor görünüyor.

- Yazışmalara şöyle bir göz atıldığında, 13 Haziran 1921 tarihli ve T.B.M.M. Özel Kaleminden Sinop Cephesi Kumandanı İnebolu'daki Refet Paşa'ya çekilen telgrafta; "Ingiliz Genel Karargahından Binbaşı Hanry ve Binbaşı Shturton'un Londra'nın resmi tahrirat ve mukarreratını bizzat tarafıma teslim için İnebolu'ya geldikleri ve Nidai Bey nezdinde bulunduklan anlaşılmıştır." diyor ve Refet Paşa'nın mektup ve belgeleri almasını, aynca Mustafa Kemal'le görüşmek gibi bir görevleri varsa bu konuda gerekenin yapılacağını bildiriyor. Mirliva Refet imzasıyla T.B.M.M. Reisi Mustafa Kemal'e çekilen 14 Haziran 1921 tarihli telgrafta da Binbaşı Hanry ve Shturton'un İstanbul'daki İngiliz Kuvvetleri Kumandanı General Harington tarafından gönderildikleri ve İnebolu'ya gelmek için cephane sevkiyatı vesilesinden faydalandıklan belirtiliyor, getirdikleri cephanenin kabul edilmesini ve Harington'un iyi niyet göstergesi sayılmasını istedikleri, Mustafa Kemal'in Boğaziçi'ndeki Harington'un yalısına gizlice giderek Harington ile barış üzerine anlaşmalannı istediklerini yazıyordu ${ }^{29}$. Hanry ve Shturton'un daha pek çok vaadlerde bulunduğu da belgede yer almaktadır.

- Bu ifadeler General Harington'un Mustafa Kemal'le görüşme konusunu gündeme getiren taraf olduğunu ortaya koymaktadır. Ancak Harington 20 Haziran 1921 tarihli ve Savunma Bakanlığına çektiği telgrafa Londra'ya konuyu açıklarken; "İnebolu'ya yollanmış olan Binbaşı Hanry aracılığıyla Mustafa Kemal'in bir mesaj gönderdiğini, kendisiyle görüşme isteğinde bulunduğunu" belirtir. Ayrıca Harington A. RawlinȘon'un anılarının ${ }^{30}$ üçüncü bölümüne yazdığı önsözde, Türkiye'deki İngiliz esirler ile Malta'daki Türklerin değiştirilmesi konusunda Dışişleri Bakanlığının kendisine yetki verdiğini, bunun üzerine Mustafa Kemal ile doğrudan temasa geçtiğini belirtmektedir. Bütün bu ifadelere rağmen Harington, Mustafa Kemal'e gönderdiği 4 Temmuz 1921 tarihli mesajda, Hanry aracılığı ile Mustafa Kemal'in görüşme isteğini öğrendiğini yazıyordu. Böylece görüşme isteğinin kimden geldiği de gündeme geliyordu. Harington Mustafa Kemal'in mesajını aldığını da belirtiyor, ama bu mesaja hiçbir yerde rastlanamıyor. Buna karşıllk İngiltere Mustafa Kemal'in görüşme isteğinde bulunduğu görüşünü hemen benimsiyordu.

29. Cumhurbaşkanlığ Arşivi, A-III-7, D. 18, F. 84/13.

30. A. Rawlinson, Adventures in The Near East, London, 1923, s. 247. 
Tabi ki, onlara göre Majestelerinin Hükümeti Milliyetçi Türkleri ve Mustafa Kemal'i muhatap alamazdı. Halbuki Hanry imzalı mektubuyla Harington'un görüşme isteğini belirtmişti ${ }^{31}$. 6 Temmuz günü Ankara'ya gelen mesaja verdiği cevapta da Mustafa Kemal, görüşme isteğinin Harington'dan geldiğini Hanry'nin beyanlanna dayanarak belirtmişti ${ }^{32}$.

- 7 Haziran'da Rattigan Hamit Beyle Hanry'nin yetkisiz olduğunu, emekli asker olduğunu bildirir. 9 Temmuz'da Royter Ajansı da bu konuda, "görüşme isteğinin İtilaf tarafından belirtilmediği, Mustafa Kemal'in görüşme isteğinde bulunduğu" şeklinde bir haber yayınlar. Anadolu Ajansı da bu konuda bir düzeltme yapar ${ }^{33}$.

- Arka arkaya siralanan bu belgelerdeki ifadeler saniyoruz ki, kimin doğru kimin yanlış söylediği konusunda bir fikir vermektedir. Üzerinde hiç tartışılmaması gereken bir nokta, Harington'un asker emeklisi de olsa, Türkiye'ye ticari amaçla da gelmiş olsa, Binbaşı Hanry'ye bazı talimatlar vermiş olduğudur. Harington İstanbul'daki Müttefik Orduları Başkumandanı'dır. Hanry ve Shturton O'nun verdiği yetkiyle Türklerle görüşmektedir. Ayrıca mesaj ve cephane getirmişlerdir ${ }^{34}$.

- Harington, Dişişlerinin kendisine esirlerin değişimi konusunda yetki verdiğini belirtirken, bu yetkiyi kullanırken aracı tayin ettiği Hanry'nin Anadolu'daki ticari beklentileri ve çıkarları yönünde kendisine verilen talimatı aşmış olduğu iddiası makul sayılabilir. Eğer İngilizler meseleyi bir gurur meselesi yapmamış ve Mustafa Kemal'le anlaşma çareleri arayan bir görüntünün kendi saygınlıklarını sarsacağı, müttefikleri ile arasını açacağı endişesiyle görüşme teklifinde bulunduklarını inkar etmiyorlarsa; ya Harington ya da Hanry yetkilerini aşmış olmalıdır. Bunlardan herhangi biri böyle bir oldu bitti ile atılacak olumlu adımın semeresini görmek istemiş olabilir. Olumsuz gelişmeler üzerine durumu kurtarmak için görüşmeyi Mustafa Kemal'in istediğini iddia etmek durumunda kalmış olabilirler. Harington'un ifadesine göre yetkilerini aşan Hanry'dir. İngiltere böyle bir oldu bitti ile karșı karşıya kalmamış ise, görüşme isteğinde bulunan taraf olmanın çıkarlarına uygun olmaması nedeniyle görüşme isteyen tarafın Türk tarafı olduğu iddiasına sığınması da mümkündür. Ancak İngiltere'yi Türklerle anlaşma zemini aramaya zor-

31. Bilal Simșir, Sakarya'dan Izmir'e, s. 87, Hanry'nin mektubu da bugüne kadar ortaya cıkmış değildir. Hanry ile Inebolu'ya gelen Shturton'un bu konuda bir raporu vardır. fkisi arasında bir karısıklık olması fikri akla yatkın görünmektedir.

32. Kemal Atatürk, Nutuk, Istanbul, 1982, C. II, s. 643.

33. Y.H. Bayur, Türkiye Devletinin Dış Siyasasıs, s. 98-99.

34. Bazı kaynaklarda bunlardan bahsedilmis olmamakla birlikte cephane getirilmesi hakkında yeterli bilgi ve Harington'un yazılı mesajının kendisi ve böyle bir mesaj olduğu konusunda da tatmin edici bilgi bulunmamaktadır. Hatta Refet Paşa yazılı bir belge veya mesaj getirmediklerini belirtmektedir. Bkz. Refet Pasa'dan Mustafa Kemal'e çekilen 14 Haziran 1921 tarihli telgraf. Cumhurbaşkanlığı Ảrş̧ivi, A-III, 7, D. 18, F. $84 / 11$. 
layan şartlar da vardır. Bu yönüyle İngiltere'nin samimi olmasa bile böyle bir teklif getirmesi mümkündür. Bunlar öncelikle yazışmalarda konu edilen esirler meselesi ile başlamak üzere, Türk-Sovyet iliş̧ileri, Mustafa Kemal Enver Paşa rekabeti, Yunan taarruzu gibi unsurlardır.

- Harington'un da ifade ettiği gibi Anadolu'daki İngiliz esirleri kurtarmak gerekiyordu. İngiliz Hükümeti resmi ilişkiye girmek istemediği için Ankara ile bu yoldan ilişkiye girerek esirlerini geri almak düşüncesinde olabilirdi. İngiliz Kamuoyunun baskısı İngiliz yetkilileri buna zorluyordu. Bu konuda, 1921 Mart ayında Bekir Sami Bey ile Londra'da yapılan esirlerin değişimi ile ilgili anlaşma da bu girişim için bir zemin oluşturuyordu.

- Aynca İngiltere, Ankara ile Sovyet Rusya'nın anlaşma imzalaması, silah ve cephane yardımı dolayısıyla, Türkiye'nin Bolşevikleşeceği endişesine düşmüştü. Rattigan da Osmanlı Hariciye Nazın ile görüşmesinde Kemalistlerin Sovyetlerin kucağına oturdukları ithamında bulunmuştu. Kafkaslarda Sovyet düzeninin kurulmasından sonra "Kafkas Seddi" projesi Türkiye'ye kaymışt ${ }^{35}$. Bu set Avrupa emperyalistlerinin Ortadoğu ve Boğazlan korumasına yardım edecekti. Bu sebeple İngiltere ya müttefik bir Türkiye, ya da en azından Sovyet güdümünde olmayan bir Türkiye istiyordu. Türklere yapılacak baskıların Türkiye'yi iyice Sovyetlere iteceği endişesi de Müttefik çevrelerinde yaşanıyordu ${ }^{36}$. Ingiltere'nin anlaşma çabası göstermesi için önemli sebeplerden biri de buydu. Bu konuda İstanbul'dan Londra'ya giden raporlar Ankara'nın gittikçe sola kaydığını, bunun sebebinin de Bolşevik nüfuzu olduğunu yazıyorlardı ${ }^{37}$. Londra da bu raporların etkisiyle telaşlanıyor, böyle bir gelişmeyi engellemeye çalışıyordu. İngilizlerin Ankara'ya yaklaşma çabalarında, "Türkiye'deki İngiliz temsilcilerinin Anadolu'da Kemalistler ile Enveristler iktidar için çarpışıyor" şeklindeki görüşleriydi. İngilizlere göre her iki grubun arkasında da Bolşevikler vardı. Ama ittihatçılar daha tehlikeliydi. Birinci Dünya Savaşı'ndan sicilleri bozuktu ve Bolşeviklere kopmamacasına bağlanabilirlerdi. Batıda temiz çıkma umutları yoktu. İngiliz Yüksek Komiserliği, Enver ve Cemal Paşalan o günlerde fiilen Bolşevik ajanları olarak değerlendiriyordu ${ }^{38}$. Enveristler başa geçerse Türkiye Bolșevik nüfuzuna kayabilirdi. Oyleyse daha ılımlı olarak görülen Mustafa Kemal iktidarda kalmalıydı. Enver Paşa'nın Anadolu'ya girme girişimlerinde bulunması da olayın tuzu biberi oluyordu.

- Ankara'da Enverciler tarafindan yapılacak bir darbeyi İngilizler kendileri açısından çok olumsuz görüyorlar, Yunanlılara aşırı davranmamalarını, Ankara'daki ılımlıların işbaşında kalarak banşı imzalamalarının

35. Yerasimos Stefanos, Türk-Sovyet Iliskkileri, Istanbul, 1979, s. 212.

36. Ali Kemal Meram, Belgelerle Türk-Ingiliz tlișkileri, Istanbul, 1989, s. 69.

37. Bilal Şimşir, Sakarya'dan Izmir'e, s. 69.

38. Bilal Șimşir, Sakarya'dan Izmir'e, s. 70. 
sağlanması gerektiğini belirtiyorlard $1^{39}$. İnebolu'da yapılan girişim bu tercihin gösterilmesi amacına yönelik olmalıydı. Enver Paşa'nın Panislamik ve Panturanist hareketlerinden de endişe duyulmuş olabilirdi.

- 1921 yılı 10 Temmuzu'nda başlayan ve Sakarya'ya kadar sürecek olan Yunan saldınsı da İngilizlerin Mustafa Kemal'le diplomatik ilişki kurma girişimlerinde etkili bir faktör olarak gösterilmektedir. Görüşme girişimleri genelde, Yunan taarruzu için Türkleri hazırlıksız bırakma teşebbüsü olarak değerlendirilmektedir. Ancak İngiliz Dışişleri Bakanı Curzon'un, Yunan saldırısının sonucundan emin olmadığı için, ne olur ne olmaz kabilinden Mustafa Kemal'le ipleri tamamen koparmamak gibi bir davranışta bulunması da gözden rak tutulmamalıdır. Inebolu görüşmelerinin gündemde olduğu sıralarda Müttefiklerin Türk-Yunan barıșı için arabuluculuğa soyunduklarından Ankara ve İstanbul'un haberi yoktu. Türklere Sevr'de bazı ödünler verilmesi söz konusu ediliyordu. Ingilizler Yunan saldınsını hazırlamaya ve başarsızlığı durumunda onu karşılamaya yönelik askeri ve siyasi çalışmalar yapmışlardı. Yunan zaferini sağlamak için askerler Türkleri barış ve görüşme laflan ile avutmaya çalışırken, diplomatlar yapılan saldırı başarısız olursa bunun olumsuzluklarını karşılamaya yönelik çalışmalarda bulunmuşlardı. Askerlerin çalışması 13 Haziran'da ve Yunan taarruzundan bir gün önce 9 Temmuz'da kesilir. Diplomatlarınki ise 18 Haziran'da başlayıp, 7 Temmuz'da biter.

- Bütün bu etkenler ve gerek her iki tarafın kendi aralarında, gerekse birbirleri ile yaptıklanı yazışmalarda geçen ifadelere göre; Mustafa Kemal'le görüşme isteğinin Londra'nın haberi olmasa bile General Harington veya Binbaşı Hanry aracılığı ile İngiltere tarafından geldiği gözlenmektedir. Belirtildiği gibi İnebolu'ya gelen İngiliz Subaylar Harington'u temsilen, Mustafa Kemal'i temsil eden Refet Paşa ile görüşmüşler ve mesaj da getirmişlerdir. İnebolu'ya cephane getirdiklerinden de bahsedilmektedir. Bu işleri amirlerinden habersiz yapmaları uzak ihtimaldir. Harington'un görüşmeyi ısrarla savunması da bu kanaati kuvvetlendirmektedir.

- İngiliz Hükümeti de olayı reddetmekle birlikte bu teklif üzerinde uzun süre tartışmıştır. Yaklaşı bir ay kadar bu konu ile ilgilenmiştir. Mustafa Kemal'e barış teklifinde bulunulması İngiltere için gurur meselesi de yapılmıştır. Bir anda ve kesin red cevabı verememişlerdir. İngiltere'nin konu ile ilgili iddialan ve yaklaşımlanının samimiyetsizliği şeklindeki görüşler de bu çerçevede biraz daha haklılık kazanmaktadır.

- Son olarak özetlemek gerekirse; ortaya atılan görüşme fikrinin gerçekte en azından diplomatlar açısından samimiyetsiz olduğu, İngiltere'nin

39. Salahi Sonyel, "Kurtuluş Savaşı Günlerinde Mustafa Kemal-Enver Çatışması", Belleten, C. 54, say1, 209, Nisan 1990, s. 396. 
bazı beklentilerine ulaşmak için oynadığı bir oyun olduğu görüşleri ağırlık kazanmaktadır. Bu konudaki görüssler ise, 10 Temmuz'da başlayacak Yunan saldırısı için Ankara'nın dikkatini barı̧̧ umutlarına çekerek gafil avlamak ${ }^{40}$, İngiliz gemisine gelecek Mustafa Kemal'i tutsak edip, veya O'nu Padişah Hükümetine teslim ederek İstanbul'da alıkoymak ${ }^{41}$. Türk-Sovyet ilişkilerini baltalayarak hem Türkiye'yi güçsüz bırakmak hem de Sovyetleşmesini engellemek, Enver Paşa-Mustafa Kemal çatışmasından yaralanmaktı. İngilizler bu iște gerçekten samimi değildiyse, Ankara'nın uyguladığı doğru politika ve her an her türlü savaşa hazırlıklı bulunması sayesinde İngilizlerin oyunu bozulmuştu.

- Sakarya Zaferi'nin ardından İngilizler Mustafa Kemal'le görüşmeye oturma fikrini yeniden gündeme getirdiler. Bu defaki Yunan ordusunun Sevr'i gerçekleştirebileceğinden ümit kesilmesinin sonucu olsa gerekti. Bu arada Ekim ayında Japonya'nın İstanbul'daki elçisi Uchida, Kasım ayında da Davidoff ve Kyrtcheff adlı Bulgarlar Ankara-Londra arasında arabuluculuk girisimlerinde bulundular. Ancak İngiltere bunların kendi zayıflığına yorulacağı görüşüyle reddetti ${ }^{42}$. İngiliz Genelkurmayı Mustafa Kemal'le görüşme isterken diplomatlar bunu zamansız ve gereksiz buluyorlardı. Nihayet 27 Kasım'da Türk-İngiliz yakınlığının kurulması için 1921 yılının son denemesi yine İnebolu'da yapıldı. 13 Haziran'da İnebolu'ya gelen Hanry tekrar gelip Refet Paşa ile görüşmeler yaptı. Bu ikinci görüşsme $27 \mathrm{Kasım}-5$ Aralık günleri arasında yapıldı. Hanry İngiltere Savunma Bakanlığı'na verdiği raporda, İngiliz diplomatların entrikaları sebebiyle Ankara ile anlaşmanın yapılamadığını, çıkmazdan kurtulmak için ilk adımın atılmasını istiyordu ${ }^{43}$. Hanry'nin bu misyonla ikinci defa İnebolu'ya gelişi Haziran ayındaki ilişkiler hakkında da bazı mesajlar veriyor. Birincisinde yetkisiz denilen, hatta emekli olduğu için cezalandırılamadığı söylenen kişinin tekrar İnebolu'ya gelmesi, İngiliz yetkililerin doğru söylemediği konusunda kanaatlere sebep oluyor. Ancak askerlerle diplomatlar arasında kesin bir görüş ayrlığı olduğu dikkate alınınca, bu girişimin askerlerce yapılıp, diplomatlarca engellendiği söylenebilir.

- İkinci İnebolu görüşmelerinde Refet Paşa'nın Harington'u ziyaret etmesi istenir. Ancak Refet Paşa Harington'a yetki verilmedikçe bunun gereksiz olduğunu savunur. Yetki verilirse görüşmeye hazır olduğunu belirtir. Hanry bu çabalar içindeyken, 12 Aralık'ta İngiliz Dışişleri Hanry'i yetkisiz ve kendi başına iş yapmakla suçladi ${ }^{44}$. Bu görüşme de daha önce-

40. Y.H. Bayur, XX. Yüzyılda Türklüğün Tarih ve Acun Siyasası Üzerindeki Etkileri, s. 218.

41. Afif Büyüktuğrul, Çanakkale Olayı, Istanbul, 1969, s. 41, ayrıca bkz. Nurettin Peker, Istiklal Savaşının Vesika ve Resimleri, s. 348.

42. Bilal Șimșir, Sakarya'dan Izmir'e, s. 215-219.

43. Bilal Șimșir, Sakarya'dan Izmir'e, s. 229-230.

44. Bilal Şimşir, Sakarya'dan Izmir'e, s. 233. 
ki gibi diplomatlar marifetiyle engellenmiş oldu. Bu konuda "De Well" gazetesi tarafindan 15 Aralık 1921 tarihli bir raporda ${ }^{45}$, İnebolu görüşmeleri ile ilgili olarak İngiliz Yüksek Komiseri Harington ${ }^{46}$, Kızılay Ikinci Başkanı Hamit Bey aracılığıyla Kemal Paşa'ya başvurmuş ve diplomatların yanı sıra dört eski subayını da vazifelendirmiștir. İngiliz diplomat, askerlerin görevlendirilmesini ve yanlış zaman seçildiğini belirtmiştir. Aynı gazetenin yorumu da İngiliz diplomatlarıyla subaylarının görüs ayrilığının barışı engellediğini savunur. Bu da daha önce belirtildiği gibi Ỉngiliz diplomatlar ile askerlerin fikir birliğinde olmadıklanını göstermektedir. Bir yerde, askerler gerçekleri görerek ona göre çıkış yolu arayıp bazı oldu bittilere de kalkışırlarken, diplomatlar Ingiliz gurur ve kibirinin etkisinden kurtulamamışlardır. İnebolu görüşmelerinin başlaması, yapılması ve sonrasındaki çelişkilerin ve tartışmaların ana sebebi bu olsa gerektir.

\section{KAYNAKLAR}

ATASE Arşivi, (Askeri Tarih ve Stratejik Etüd Dairesi Arşivi).

Atatürk, Kemal, Nutuk, Milli Eğitim Bakanlığı Yayını, Istanbul, 1982.

Bayur, Y. Hikmet, Türkiye Devletinin Dış Siyasası, Ankara, 1973.

XX. Yüzyılda Türklüğün Tarih ve Acun Siyasası Üzerindeki Etkileri, Ankara, 1974.

Büyüktuğrul, Afif, Çanakkale Olayı, Istanbul, 1969.

Jaescke, Gotthard, Kurtuluş Savaşı Ile Ilgili Ingiliz Belgeleri, Ankara, 1986, Çev. Cemal Köprülü.

Kerman, Zeynep, Belçika Temsilciliği Vesikalarına Göre Milli Mücadele, Istanbul, 1982.

Meram, Ali Kemal, Belgelerle Türk-Ingiliz Ilişkileri, Istanbul, 1969.

Peker, Nurettin, Istiklal Savaşının Vesika ve Resimleri, Istanbul, 1955.

Rawlinson, A., Edvantures in The Near East, London, 1923.

Sonyel, Salahi, "Kurtuluş Savașı Günlerinde Mustafa Kemal-Enver Çatışması", Belleten, C. 54, Say1: 209, Nisan 1990

Stefanos, Yerasimos, Türk-Sovyet Ilişkileri, Istanbul, 1979.

Şimşir, Bilal, Ingiliz Belgelerinde Atatürk, C. III, Ankara, 1979.

-.----, Ingiliz Belgeleri Ile Sakarya'dan Izmir'e, Istanbul, 1989.

45. Zeynep Kerman, Belçika Temsilciliği Vesikalarına Göre Milli Mücadele, Istanbul, 1982, s. 42.

46. General Harington Müttefik Ordulan Kumandanıdır. Yüksek Komiser ifadesi yanlışlıkla geçmiş olmalıdır. 